\title{
AHMAD SYAFII MAARIF: KAJIAN SOSIAL-INTELEKTUAL DAN MODEL GAGASAN KEISLAMANNYA
}

\author{
Muhammad Qorib \\ Dosen Fakultas Agama Islam Universitas Muhammadiyah Sumatera Utara \\ (Email: muhammadqorib@ umsu.ac.id)
}

\begin{abstract}
Abstrak
Salah satu tokoh pemikiran Islam di Indonesia yang turut serta menciptakan dinamika pemikiran Islam adalah Ahmad Syafii Maarif. Lahir dari kultur Minang yang kaya dengan berbagai kearifan dan kental nuansa keislaman membuat Syafii Maarif akrab dengan ajaran Islam. Situasi sosial tersebut memberikan pengaruh besar terhadap bangunan intelektual Syafii maarif selanjutnya. Meskipun lahir dari keluarga yang sangat sederhana, namun ia memiliki kemauan yang cukup keras untuk terus belajar hingga ke fase pendidikan yang paling tinggi. Tradisi merantau yang telah mendarahdaging bagi masyarakat Minang mengantarkan Syafii Maarif meninggalkan kampung halaman untuk menimba ilmu dan pengalaman di berbagai tempat, sampai pada akhirnya ia terdampar di Ohio Athens dan Chicago Amerika Serikat ketika menyelesaikan program master dan doktornya. Pemikiran keislaman Syafii Maarif ditandai oleh Alquran sebagai kerangka berpikir dan sejarah sebagai analisisnya. Dua hal itu menjadi ciri khas model berpikir Syafii Maarif.
\end{abstract}

Keywords: Islam, Sumpur Kudus, Alquran, Sejarah, Titik-Titik Kisar

\section{A. Pendahuluan}

Perkembangan pemikiran Islam

di Indonesia menunjukkan dinamika

yang cukup menggembirakan.

Berbagai faktor memberikan

pengaruh yang tidak kecil, salah

satunya adalah kontribusi para tokoh

pemikiran Islam dari berbagai

perspektif. Meskipun terkadang lahir

ketegangan akademik, namun peran serta mereka untuk membangun

kerangka akademik patut diapresiasi.

Salah satu tokoh penting pemikiran

Islam di Indonesia adalah Ahmad
Syafii Maarif. Tidak saja secara individual, Ahmad Syafii Maarif melalui Muhammadiyah yang pernah dipimpinnya turut serta mendorong gerakan intelektualisme di Indonesia. Tulisan ini mengkaji model pemikiran Islam Ahmad Syafii Maarif, budaya yang mengitarinya dan analisis terhadap karya-karya yang ditulisnya.

\section{B. Implikasi Kultur Minang}

Ahmad Syafii
(selanjutnya ditulis Syafii Maarif)
dilahirkan di Sumpur Kudus pada


tanggal 31 Mei 1935 dari pasangan Ma'rifah (ayah) (1900-1955) dan Fathiyah (ibu) (lahir kira-kira 19051937) ${ }^{1}$ sebagai anak bungsu dari empat bersaudara. ${ }^{2}$ Ayahnya adalah tokoh yang terpandang di kampungnya. Ia berstatus sebagai kepada suku Malayu dengan gelar Datok Rajo Malayu dan sebagai Kepala Nagari. Masyarakat Minang dikenal berkarakter egaliter, namun di antara suku-suku itu, Chaniago adalah suku yang paling egaliter. Fathiyah, Ibu Syafii Maarif, berasal dari suku itu. ${ }^{3}$ Dapat diduga, selain terpengaruh oleh pendidikan Barat yang memang egaliter, sikap Syafii Maarif yang egaliter bisa saja dibentuk oleh kultur Minang itu. Dugaan ini diperkuat oleh tesis Mrazek yang menjelaskan bahwa masyarakat Minang bercirikan dua hal, yaitu: pertama, dinamisme, dan kedua, anti-parokialisme. Yang pertama ditandai dengan jiwa merantau, ${ }^{4}$ sedang yang kedua

${ }^{1}$ Fathiyah wafat saat Syafii Maarif berusia 18 bulan. Ahmad Syafii Maarif, TitikTitik Kisar dalam Perjalananku (Yogyakarta: Ombak, 2006), h. 42.

${ }^{2}$ Ahmad Syafii Maarif, Ibid., h. viii dan 4.

${ }^{3}$ Ibid., h. viii.

4 Lihat Tsuyosi Kato, Adat Minangkabau dan Merantau dalam melahirkan jiwa bebas yang kosmopolit. $^{5}$ Meskipun lahir di wilayah pedesaan, secara ideologis, Syafii Maarif dibesarkan dalam nuansa maritim yang dinamis dan independen. ${ }^{6}$ Karakter inilah yang kelak mewarnai gagasan-gagasan yang ia gulirkan.

Sumpur Kudus juga disebut dengan "Makkah Darat." Secara kultural sebutan itu menunjukkan sebuah gerak perlawanan Islam terhadap kultur jahiliyah yang dikuasai para parewa (preman). Penamaan Sumpur Kudus (sampurna

Perspektif Sejarah (Jakarta: Balai Pustaka, 2005).

${ }^{5}$ Ahmad Syafii Maarif, Op.Cit., h. xi.

6 Mattulada membagi kepemimpinan (karakter masyarakat), ke dalam tiga model, yaitu: Pertama, model kepemimpinan agraris. Model kepemimpinan ini biasanya menjadikan para pemimpin dan pemuka masyarakat sebagai sumber inspirasi dalam berpikir dan bertindak. Biasanya model kepemimpinan seperti ini ada di daerah Jawa dan Sunda. Jawa dengan konsep Pakubuwono (sentralistik) menjadikan para pemimpin dan pemerintah pusat sebagai ukuran. Kedua, model kepemimpinan Melayu (menjinjing alam). Model ini memungkinkan masyarakat memiliki pendapat yang berbeda antara yang satu dengan lainnya. Model ini juga mencerminkan suasana yang demokratis. Ketiga, model kepemimpinan maritim (kapitan laut). Model ini mensyaratkan setiap orang untuk berupaya semaksimal mungkin untuk sampai ke puncak piramida sosial yang tertinggi. Kecuali yang pertama, kultur Minang lebih mendekati model kedua dan ketiga. Dikutip dari Kusnadi, Jaminan Sosial Nelayan (Yogyakarta: LKiS, 2007), h. 2122. 
suci) sebagai Makkah Darat sekaligus menunjukkan keberhasilan Islam menundukkan hati manusia Sumpur Kudus. ${ }^{7}$ Dapat dipahami, ia lahir di tengah kultur dan dinamika keislaman yang kental itu. Makkah Darat merupakan pusat gerakan dan kajian Islam yang jauh dari pantai (Barat dan Timur). Istilah "adat nan menurun, syarak nan mendaki" harus dilihat dari gerak adat dari tempat yang tinggi dari Pariangan Padang Panjang di lereng Gunung Merapi. Syarak mendaki dari dataran rendah pantai timur dan dari Ulakan di pantai barat menuju tempat yang tinggi. ${ }^{8}$ Gerak turun dan mendaki inilah kemudian melahirkan formula strategis berupa "adat bersendi syarak, syarak bersendi kitabullah", dan "syarak mengata adat memakai" (syarak mangato adaik mamakai, dalam bahasa Minang), sekalipun masih banyak unsur adat itu yang berlawanan dengan agama. ${ }^{9}$

Selain kaya akan nilai-nilai tradisi, Sumpur Kudus juga merupakan pusat perdagangan emas dan kopi. Dua barang dagangan itu

\footnotetext{
${ }^{7}$ Ahmad Syafii Maarif, Op. Cit., h. viii.

${ }^{8}$ Ibid., h. 8.

${ }^{9}$ Ibid., h. 8 .
}

bukan hanya menjadi kebanggaan masyarakat, tapi juga menjadi barang ekspor ke luar negeri. Emas dan kopi tersebut diangkut ke Singapura via Riau, untuk kemudian dikirim ke Eropa. ${ }^{10}$ Situasi seperti itu juga ditegaskan Christine E. Dobbin tentang kemajuan Sumpur Kudus. ${ }^{11}$ Hubungan antara Sumpur Kudus dengan dunia luar merupakan sebuah bukti bahwa daerah ini terbuka dengan berbagai kultur lain. Sebagai sebuah pusat dagang, tentunya daerah tersebut merupakan tempat bertemunya para pendatang dengan latar belakang kultur yang majemuk. ${ }^{12}$ Latar belakang budaya yang kaya, kultur keislaman yang kental dan dinamika masyarakat yang tinggi adalah nilai lebih tersendiri bagi terbangunnya watak yang religius, egaliter dan mandiri. Seperti diakui oleh Syafii Maarif, latar belakang potensi tersebut begitu membekas

${ }^{10}$ Ibid., h. 13-14.

11 Ibid., h. 15-16. Uraian lengkapnya dapat dibaca melalui karya Christine E. Dobbin, Islamic Revivalism in A Changing Peasant Economy: Central Sumatera 17841847 (London: Curzon Press, 1983).

12 Howard M. Federspiel, Sultans, Shammans \& Sains: Islam and Muslim in South East Asia (Hawai: University of Hawai Press, 2007), h. 38. 
dalam

pengembangan

kepribadiannya. $^{13}$

Jasa masyarakat Sumpur Kudus juga tidak boleh diabaikan, mengingat pada tahun 1949 Pemerintah Darurat Republik Indonesia (PDRI) pimpinan Syafruddin Prawiranegara (19111989) diselenggarakan di sana. ${ }^{14}$ Menurut Syafii Maarif, jika PDRI itu tidak ada, maka Sumpus Kudus tidak akan banyak dibicarakan orang ${ }^{15}$ dan mungkin saja tidak dikenal. Bagi penulis sendiri, tentunya pernyataan itu merupakan indikasi dari sikap kritisnya. Ia ingin menunjukkan bahwa secara historis Sumpur Kudus turut memberikan jasanya untuk penanaman ide nasionalisme. Tapi pada sisi tertentu daerah tersebut kurang mendapat perhatian dalam 17.

${ }^{13}$ Ahmad Syafii Maarif, Op. Cit., h.

${ }^{14}$ Marwati Djoened Poesponegoro dan Nugroho Notosusanto, Sejarah Nasional Indonesia VI: Zaman Jepang dan Zaman Republik Indonesia (Jakarta: Balai Pustaka, 1992), h. 266; Audrey Kahin, Dari Pemberontakan ke Integrasi: Sumatera Barat dan Politik Indonesia 1926-1998 (Jakarta: Yayasan Obor, 2005); Taufik Abdullah, "PDRI, Kesadaran Sejarah dan Masa Kini", dalam Jurnal Sejarah, no. 13 Vol. 13, (2007), h. 13-27; Es Ito, Negara Kelima: Memperingati 100 Tahun Kebangkitan Nasional (Jakarta: Serambi, 2005); Mohammad Iskandar et al., Peranan Desa dalam Perjuangan Kemerdekaan di Sumatera Barat 1945-1950 (Jakarta: Depdikbud, 1998).

${ }^{15}$ Ahmad Syafii Maarif, Op.Cit., h. 4. proses pembangunan. ${ }^{16}$ Jika Sumpur Kudus tidak banyak dibicarakan orang, tentunya hal ini berbanding terbalik dengan berbagai tulisan yang mengangkat isu seputar daerah itu.

Kultur Minang yang demokratis dan egaliter itu telah melahirkan tokoh-tokoh besar yang amat berpengaruh di negeri ini. Tentu saja disinilah pentingnya, khususnya orang Minang, untuk mengetahui setting sejarah masyarakat Minang. Seorang Tan Malaka (lahir 1896 di Nagari Pandan Gadang, Suliki, dan terbunuh 1949 di Jawa Timur) pernah menjadi tokoh Komintern (Komunis Internasional), tentu ia diilhami oleh semangat "Alam terkembang menjadi guru”. Begitu pula dengan tokohtokoh seperti Agus Salim (18841954), Hatta (1902-1980), Natsir (1908-1993), Sjahrir (1909-1966), Bahder Djohan (1902-tidak diketahui), Hamka (1908-1981), Isa

16 Hal itu dapat dilihat dari pemasangan arus listrik yang terlambat ke Sumpur Kudus. Setelah Indonesia merdeka tanggal 17 Agustus 1945, maka Sumpur Kudus merdeka dari kegelapan pada tanggal 29 Januari 2005, setelah listrik masuk desa. Jika ukuran ukuran kemerdekaannya dilihat dari standar listrik masuk desa. Baca Ahmad Syafii Maarif, "Sumpur Kudus Setelah Merdeka," Harian Republika, 25 Februari 2005. 
Anshari (1916-1969), lahir dari rahim ranah Minang. ${ }^{17}$

\section{B. Evolusi Intelektual}

Untuk melacak rekam jejak (track record) perkembangan intelektual Syafii Maarif, ada tiga tahapan yang tidak boleh dilupakan. Meminjam istilah yang dipakainya, ketiga tahapan itu disebut dengan titik-titik kisar. ${ }^{18}$ Titik kisar pertama, terjadi ketika ia mengecap pendidikan di Madrasah Mu'allimin Muhammadiyah di Balai Tangah, Lintau setelah menganggur selama tiga tahun pasca Sekolah Rakyat (1947). ${ }^{19} \quad$ Latar $\quad$ pendidikan

${ }^{17}$ Ahmad Syafii Maarif, Op. Cit., h. 59. Demikian pula ketokohan Syafii Maarif, subjek dalam penelitian ini. Konstruksi berpikirnya tentu saja amat ditentukan oleh warna budaya Minang yang kaya itu.

18 Titik-Titik Kisar di sini diartikan dengan keberuntungan dan kesempatan sang tokoh dalam menjalani hidup dan meraih pendidikan, dapat pula diartikan dengan tahapan-tahapan yang dilalui.

19 Seperti disebutkan dalam otobiografinya bahwa Muhammadiyah sudah memasuki Sumpur Kudus pada tahun 1943, masih Perang Dunia II (1939-1945), atau 18 tahun setelah gerakan Islam modern ini masuk ke Sungai Batang, Tanjungsani, Maninjau, pada tahun 1925. Pelopor utamanya adalah H. Abdul Karim Amarullah (1879-1945), Jusuf Amarullah (lahir dan wafat tidak ditemukan), A.R. Sutan Mansur (1895-tidak diketahui), Hamka (1908-1981), dan diikuti generasi sesudahnya. Ahmad Syafii Maarif, Op. Cit., h. 12. Lihat "Syafii Maarif', [home page on-line], didapat dari
Muhammadiyah ini membentuknya menjadi pribadi yang pemberani secara intelektual. Ruh pendidikan Muhammadiyah yang pertama dipompakan ke dalam lokus intelektual Syafii Maarif menjadi modal awal bagi perkembangan pemikirannya lebih lanjut.

Titik kisar kedua, terjadi setelah meneruskan pelajaran ke Madrasah Mu'allimin Yogyakarta dan selesai tahun 1956. Wawasannya semakin luas, tetapi nalurinya sebagai seorang "fundamentalis" belum berubah, jika bukan semakin menguat. Bahkan sampai ia belajar sejarah pada Universitas Ohio di Athens, Amerika Serikat, paham agamanya belum banyak mengalami perubahan. Citacita politik Syafii Maarif tetap saja ingin menjadikan Indonesia agar menjadi Negara Islam.

Titik kisar ketiga, terjadi pada saat ia mengikuti program doktor di Universitas Chicago, Amerika Serikat, selesai tahun 1983. Di universitas tersebut, ia mengalami titik balik intelektual secara signifikan. Di bawah bimbingan

http://www.muhammadiyah.or.id; Internet (diakses pada tanggal 28 Februari 2010). 
Fazlur Rahman (1919-1988), Syafii

Maarif memiliki pandangan yang realistis dan rasional tentang Islam ini. $^{20}$ Setelah melalui titik kisar ketiga, ia memantapkan diri sebagai seorang pemikir Muslim yang intens mengkaji relasi antara Islam, Indonesia dan nilai-nilai kemanusiaan. Hal tersebut belakangan harus ia bayar mahal dengan sejumlah predikat yang terkesan peyoratif (mengejek), seperti: "hanya membebek pikiran Rahman", "pembawa sekularisme", "anti-Piagam Jakarta". Dengan keteguhan dan kematangan intelektual, hal itu tidak membuatnya terinterupsi untuk terus menyampaikan pemikiranpemikirannya dalam perspektif sosiologis keindonesiaan.

Selain Fazlur Rahman, Mohammad Hatta turut memberikan pengaruh terhadap perkembangan intelektual Syafii Maarif. Dalam beberapa tulisannya, Syafii Maarif memberikan apresiasi yang cukup

\footnotetext{
20 Nurcholish Madjid, "Kata Pengantar", dalam Ahmad Syafii Maarif, Islam dan Masalah Kenegaraan: Studi tentang Peraturan dalam Konstituante (Yogyakarta: LP3ES, 1984), h. xiii.
}

tinggi terhadap pemikiran dan aktivisme Hatta. Syafii Maarif juga menyebut Hatta sebagai seorang moralis sejati. Darinya Syafii Maarif mendapatkan spirit di mana nilai-nilai moral mesti ditegakkan walaupun harus berhadapan dengan kekuasaan yang cukup kokoh. Selain itu, Syafii Maarif juga belajar bagaimana memahami Islam secara substansial. Hatta selalu menegaskan bahwa substansi nilai-nilai Islam yang dipraktikkan dalam kehidupan jauh lebih penting ketimbang mengedepankan sisi formal agama. ${ }^{21}$ Bahkan Hatta menjadi rujukan Syafii Maarif ketika menafsirkan sila-sila dalam Pancasila. Bagi Hatta, Pancasila dapat diterima dan sejalan dengan nilai-nilai Islam, karena itu tidak ada alasan menolak Pancasila tersebut. Pemikiran dan aktivisme Hatta itulah yang menginspirasi Syafii Maarif untuk melakukan hal serupa. $^{22}$

Tentang penilaian Syafii Maarif mengenai Hatta ini, ada persoalan

21 Ahmad Syafii Maarif, Mencari Autentisitas di Tengah Kegalauan (Jakarta: PSAP, 2004), h. 229-232.

22 Ahmad Syafii Maarif, Islam dan Masalah Kenegaraan, Ibid., h. 152-157. 
mendasar yang perlu dicermati. Syafii Maarif dalam mengembangkan Meskipun Hatta merupakan seorang moralis sejati seperti predikat yang disematkan Syafii Maarif kepadanya, namun ia juga sebagai seorang manusia biasa yang tidak luput dari berbagai kekeliruan. Di sini, Syafii Maarif terkesan mengidealisasikan Hatta secara berlebihan sehingga yang ditampilkan dari Hatta hanya sisi positifnya saja. Dalam banyak hal, Syafii Maarif terlihat demikian kritis termasuk ketika ia memaparkan kepemimpinan Soekarno dalam era demokrasi terpimpin. Dalam uraiannya, Syafii Maarif menyebut Soekarno sebagai pemimpin yang cukup otoriter. Di sisi lain Syafii Maarif memberikan apresiasi yang tinggi kepada Soekarno karena secara brilian ia dapat merumuskan sila-sila dalam Pancasila. Objektivitas penilaian Syafii Maarif cukup jelas di situ. Terkait dengan pribadi dan pemikiran Hatta, Syafii Maarif seperti menerimanya tanpa sikap kritis. Dalam konteks ini, tidak dijumpai uraian yang menjadi alasannya bersikap demikian.

Secara khusus, perlu pula diketahui beberapa fase yang dilalui 
itu, ia mendukung bahkan mengembangkan ide-ide modern secara deklaratif termasuk ide tentang pluralisme. Apalagi wacana itu mendapat respons dari berbagai komunitas akademik baik dari komunitas yang mendukungnya maupun yang memberikan kritik kepadanya.

Daya dobrak yang dihasilkan dari dinamika intelektual Syafii Maarif mendapatkan momentumnya setelah ia terpilih sebagai Ketua Umum Pimpinan Pusat Muhammadiyah tahun 2000 di Jakarta. $^{23}$ Jika ditelisik lebih jauh, intelektualisme Syafii Maarif tidak

${ }^{23}$ Meski sejak kecil sudah mengenal Muhammadiyah, Syafii Maarif baru benarbenar menjadi pengurus organisasi Islam itu sepulang dari Chicago. Waktu itu, tahun 1985, ia diajak masuk ke Majelis Tabligh Muhammadiyah, sampai akhirnya "gelombang" menghempaskannya menjadi Ketua PP Muhammadiyah pada 1998, menggantikan Amien Rais yang ketika itu memilih terjun ke panggung politik praktis. Jabatan ketua itu, sebenarnya juga bukan tiba-tiba diraihnya. Dalam beberapa kali Muktamar organisasi keagamaan tersebut, ia setidaknya sudah dua kali masuk bursa ketua. Muktamar di Solo ia masuk calon nomor dua belas dan di Banda Aceh masuk calon nomor tiga. Baru pada Muktamar ke-44 di Jakarta, ia terpilih sebagai Ketua Umum Pimpinan Pusat Muhammadiyah 2000-2005. "Syafii Maarif," [home page on line], didapat dari http://www.pdat.co.id/ads/html/A/ads,200307 01-32,A.html; Internet (diakses pada tanggal 28 Februari 2010). hanya sebatas gagasan-gagasan normatif, melainkan terwujud dalam aktivitasnya secara riil. Bahkan M. Amin Abdullah mensejajarkan sosok Maarif dengan Ali Syari'ati (19331977), intelektual Iran itu. ${ }^{24}$ Abdullah beralasan bahwa sosok Syafii Maarif merupakan intelektual sekaligus aktivis pergerakan yang memiliki kapasitas sosial amat tinggi. ${ }^{25}$ Dengan perspektif ini, ia lebih tepat disebut

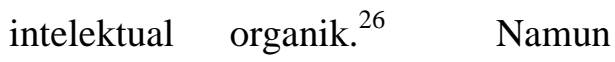
demikian, perkembangan intelektualnya terbilang lambat. Ia mendapatkan gelar doktor di usia 48 tahun, kemudian meraih predikat Guru Besar Sejarah dari IKIP Yogyakarta di usia 62 tahun. Tentu saja, kenyataan itu wajar saja

24 M. Amin Abdullah, "Intelektual Sekaligus Aktivis", dalam Abdul Rahim Ghazali dan Saleh Partaonan Daulay, eds., Cermin untuk Semua: Refleksi 70 Tahun Ahmad Syafii Maarif (Jakarta: Maarif Institue, 2005), h. 18.

${ }^{25}$ M. Amin Abdullah, Ibid., h. 18.

${ }^{26}$ Intelektual organik disebut pula man of thought and man of action. Lihat Antonio Gramsci, Selections from the Prison Notebooks (London: Laurence \& Wishart, 1971); Yudi Latif, Inteligensia Muslim dan Kuasa: Genealogi Inteligensia Muslim Indonesia Abad ke-20 (Bandung: Mizan, 2005); H.A.R. Tilaar, Kekuasaan dan Pendidikan: Suatu Tinjauan dari Perspektif Studi Kultural (Magelang: Indonesia Kita, 2003), 77; Moeslim Abdurrahman, Islam sebagai Kritik Sosial (Jakarta: Erlangga, 2003). 
mengingat perjalanan hidupnya amat berliku. $^{27}$

\section{Metode yang Dipakai}

Ada empat hal penting yang digunakan Syafii Maarif sebagai dasar dalam membangun gagasan keislamannya:

Pertama, Alquran sebagai sebuah petunjuk dan sistem moral memiliki cakupan makna yang begitu luas dan dapat dijadikan pedoman dasar bagi arah pembangunan. Sebagai sebuah prinsip moral, Alquran tidak bersifat elitis. Ia terbuka bagi semua kaum bernalar yang mencari kebenaran dan kebajikan dan Alquran merupakan "korpus terbuka" yang

27 Lihat Ahmad Syafii Maarif, TitikTitik Kisar. Perkembangan intelektualisme Syafii Maarif dapat penulis umpamakan sebagai sebuah benih yang kemudian menemukan lahan suburnya. Sikap demokratis, egaliter, mandiri, nasionalis dan religius tumbuh seiring dengan masa-masa (formative years) di mana ia dibesarkan. Tentunya, hal itu amat membekas dalam mind set (pola pikir)-nya. Beragam karakter positif itu merupakan benih bawaan dari kultur Minang yang terus diasah oleh Syafii Maarif. Hal itu tumbuh subur sehingga membentuk sebuah kepribadian khas. Proses lahirnya intelektualisme itu terjadi setelah melalui berbagai pencarian, baik secara akademik maupun sosial. Kegelisahan demi kegelisahan itulah yang pada akhirnya mewujud dalam berbagai gagasan seperti yang dikembangkannya saat ini. memungkinkan lahirnya interpretasiinterpretasi baru yang sesuai dengan konteks zamannya. Namun kemudian Syafii Maarif menyadari bahwa menemukan kompatibilitas antara Alquran dengan perkembangan dunia modern bukanlah persoalan mudah. Hal ini membutuhkan kerja besar dan strategis termasuk keberanian melakukan ijtihad-ijtihad baru. ${ }^{28}$

Kedua, kitab suci umat Islam ini bagi Syafii Maarif lebih merupakan sumber moral (moral source) bagi kaum Muslim untuk menciptakan keadilan dan kebaikan, ketimbang kitab yang secara literal hanya berisi pranata legal. Karena itu, dalam konteks kehidupan bangsa Indonesia, nilai-nilai Alquran mesti dikontekstualisasikan bukan sebaliknya diterima apa adanya tanpa refleksi kritis. $^{29}$

Ketiga, dalam memahami Alquran selalu ada jarak menganga

28 Lihat Ahmad Syafii Maarif, AlQur'an, Realitas Sosial dan Limbo Sejarah: Sebuah Refleksi (Bandung: Pustaka, 1985), h. 2-7. Redaksi pada paragraf ini dikutip dari Hilman Latief, "Ahmad Syafii Maarif: Pengarusutamaan Moderasi Islam Indonesia", dalam Ahmad Suaedi dan Raja Juli Antoni, ed. Para Pembaharu Pemikiran dan Gerakan Islam Asia Tenggara (Jakarta: Seamus, 2009), h. 262-263.

${ }^{29}$ Hilman Latief, Ibid., h. 263. 
antara idealita dengan realita. Kontestasi antara nilai idealitas Alquran dan kepentingan pragmatis di bidang sosial, ekonomi dan politik adalah bagian integral kehidupan seorang Muslim. Terkadang Alquran sering dijadikan perebutan otoritas mazhab. Oleh sebab itu, Syafii Maarif menegaskan bahwa makna universal Alquran harus dapat "menundukkan" kepentingan-kepentingan pragmatis manusia, bukan sebaliknya. ${ }^{30}$

Keempat, sebagai seorang peminat sejarah Syafii Maarif kerap memotret situasi dan kondisi perkembangan masyarakat dengan pendekatan disiplin ilmu ini. Bagi Syafii Maarif, sejarah merupakan penunjuk bagi umat yang datang kemudian. Di dalamnya, pertumbuhan, perkembangan, kemajuan dan kejatuhan umat manusia terjadi. Ada dua hal yang dapat dipetik dari penggunakan paradigma sejarah: Pertama, kejadiankejadian di masa lampau secara substansial akan terjadi kembali di masa yang akan datang. Karena itu, sejarah merupakan laboratorium hikmah di mana pedoman hidup dapat

\footnotetext{
${ }^{30}$ Ibid., h. 263.
}

digali. Kedua, masa depan secara hakiki merupakan konsekuensi dari masa lampau dan masa kini. Karena berkesinambungan, perspektif sejarah memegang peranan signifikan. ${ }^{31}$

Syafii Maarif membagi Islam ke dalam dua ketegori, yaitu: "Islam Qur'anis" dan "Islam Historis", atau dalam bahasa lain ia menggunakan istilah "Islam idealita" dan "Islam realita". Menurutnya, "Islam Qur'anis" adalah Islam yang mewakili pandangan total dunia Islam yang didasarkan pada interpretasi murni dan otentik dari Alquran. Sedangkan "Islam Historis" adalah Islam yang muncul dari interaksinya dan pertarungannya dengan darah daging sejarah, yang tidak selalu sesuai dengan misi kenabian sebagai rahmat bagi alam semesta. ${ }^{32}$ Secara lebih konkret, metode berpikir Syafii Maarif dapat dilihat dalam peta konsep berikut:

${ }^{31}$ Lihat pemaparannya dalam Ahmad Syafii Maarif, Mencari Autentisitas di Tengah Kegalauan (Jakarta: PSAP, 2005).

${ }^{32}$ Hilman Latief, Op.Cit., h. 263-264. 


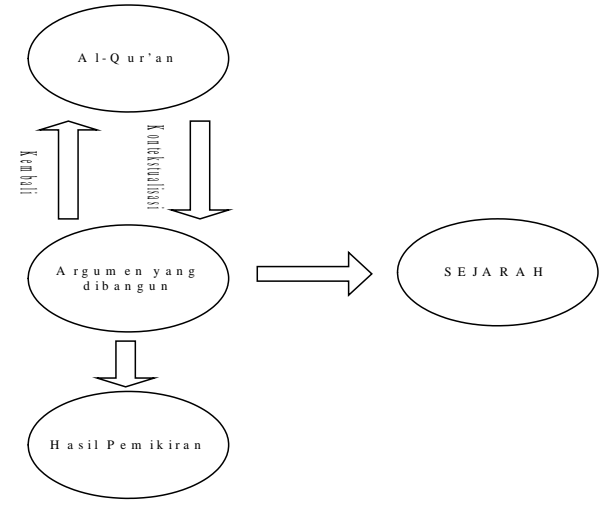

Namun demikian, Syafii Maarif jarang mengutip hadis sebagai sumber di mana ia menemukan spirit untuk pemikiran dan gerakannya. Sebagai tokoh yang mendalami kajian Islam, mestinya ia selalu menggunakan sumber kedua itu sebagaimana Alquran. Demikian pula dengan berbagai literatur Islam klasik. Untuk memperluas wawasannya, literatur Islam klasik dapat dikatakan penting. Kenyataannya tidak demikian, meskipun ia mengutip beberapa hadis dan menggunakan beberapa literatur Islam klasik namun dalam jumlah yang terbatas. Hal ini dapat dilihat misalnya ketika ia menulis buku utuh Islam dalam Bingkai Keindonesiaan dan Kemanusiaan: Sebuah Refleksi Sejarah (2009), ${ }^{33}$ kitab hadis maupun

\footnotetext{
${ }^{33}$ Lihat Ahmad Syafii Maarif, Islam dalam Bingkai Keindonesiaan dan Kemanusiaan: Sebuah Refleksi Sejarah (Bandung: Mizan, 2009).
}

literatur Islam klasik hanya berjumlah sembilan buah dari 154 buku yang digunakannya sebagai rujukan. Selain itu, dalam bukunya Al-Qur'an dan Realitas Umat (2010), Syafii Maarif hanya merujuk tafsir Al-Azhar karangan Hamka ketika memahami ayat 62 surah al-Baqarah dan ayat 69 surah al-Ma >'idah. Meskipun hal itu dapat dimengerti karena pemahaman itu dipersiapkan untuk tulisan lepas. Kenyataan ini semestinya mendapat perhatian dari Syafii Maarif. Sebagai seorang tokoh Muhammadiyah dengan moto "al-ruj'u ila> alQur'a>n wa al-sunnah (kembali kepada Alquran dan sunnah)" mestinya khasanah Islam klasik itu menyatu di dalam kapabilitas intelektualnya.

\section{Analisis Terhadap Karya-}

\section{Karyanya}

Syafii Maarif termasuk tokoh produktif yang telah melahirkan berbagai tulisan. Secara garis besar, gagasan-gagasannya dapat dikelompokkan ke dalam beberapa persoalan: Pertama, persoalan global. Kedua, persoalan nasional. Dari persoalan global dan persoalan 
nasional tersebut, isu yang menjadi fokus pemikirannya adalah tentang "Keislaman", "keindonesiaan", "kemanusiaan". Rekaman pemikiran Syafii Maarif dapat dilacak lewat buku-buku yang ia tulis. Buku-buku itu penulis kelompokkan ke dalam beberapa bagian: Pertama, buku utuh. Pemaparan yang dikemukakan dalam buku ini bersifat komprehensif. Kedua, buku semi utuh. Buku ini merupakan kumpulan makalah ilmiah yang ia tulis untuk berbagai seminar. Ketiga, buku populer. Buku ini berisi kumpulan tulisan tetap maupun lepas di berbagai media massa. Keempat, naskah khutbah Jum'at yang kemudian ditranskripkan dan dijadikan sebuah buku. Berbagai pemikirannya yang lain juga dapat dilacak melalui tulisan-tulisan dan berbagai wawancara yang belum diedit dan ditranskripkan. Karyakarya tersebut sebagai berikut:

1. Gilad Atzmon: Catatan Kritikal tentang Palestina dan Masa Depan Zionisme. ${ }^{34}$ Karya ini merupakan buku

\footnotetext{
4 Ahmad Syafii Maarif, Gilad Atzmon: Catatan Kritikal tentang Palestina dan Masa Depan Zionisme (Bandung: Mizan dan MAARIF Institute, 2012).
}

utuh yang dihasilkan dari interaksi antara Syafii Maarif dengan Gilad Atzmon, seorang Yahudi yang anti zionisme, melalui dunia maya (internet). Dalam buku ini, Syafii Maarif menempatkan Atzmon sebagai pejuang kemanusiaan. Alasan yang mendasari predikat itu didapat dari fakta bahwa Atzmon memberikan kritik-kritik yang cukup tajam kepada Negara Israel. Hal yang cukup mengejutkan bahwa Atzmon menyebut Negara Israel dibangun di atas berbagai pelanggaran kemanusiaan. Buku ini juga menunjukkan bahwa tidak semua orang Yahudi setuju dengan politik luar negeri yang dipraktikkan Israel. Poin yang termasuk penting dalam buku ini terletak pada penempatan istilah Yahudi, Israel, dan Zionisme secara proporsional. Tidak semua Yahudi itu Israel dan tidak semua masyarakat Israel setuju dengan gerakan Zionisme. Zionisme adalah 
sebuah gerakan politik dalam jumlah yang kecil namun memiliki kekuasaan.

2. Al-Qur'an dan Realitas Umat. $^{35}$ Karya ini merupakan buku populer yang berasal dari berbagai tulisan di media massa lalu diedit dan dijadikan buku. Dalam buku ini Syafii Maarif menjelaskan bahwa umat Islam pada tataran global saling merasa yang paling benar dibanding lainnya. Melihat kenyataan ini, ia mengajak seluruh elemen umat Islam untuk mencari solusi dengan kembali kepada Alquran sehingga Alquran dapat berfungsi kembali dalam memecahkan masalah fundamental itu.

3. Islam dalam Bingkai Keindonesiaan dan Kemanusiaan: Sebuah Refleksi Sejarah. ${ }^{36}$ Karya ini

35 Ahmad Syafii Maarif, Al-Qur'an dan Realitas Umat (Jakarta: Republika, 2010).

${ }^{36}$ Ahmad Syafii Maarif, Islam dalam Bingkai Keindonesiaan dan Kemanusiaan: Sebuah Refleksi Sejarah (Bandung: Mizan, 2009). merupakan buku utuh yang penting. Syafii Maarif menjelaskan keterkaitan antara keislaman, keindonesiaan dan kemanusiaan. Tentunya bagi penulis sendiri buku ini merupakan referensi utama berkenaan dengan penelitian penulis.

4. Titik-Titik Kisar dalam Perjalananku: Otobiografi. ${ }^{37}$ Karya ini merupakan buku komprehensif tentang perjalanan hidup Syafii Maarif, mulai dari lahir sampai kini. Untuk memotret sosok Syafii Maarif yang sesungguhnya, buku ini dapat dijadikan referensi utama. Meskipun terdapat unsur subjektivitas, karena ditulis sendiri, namun buku itu penuh dengan nuansa kejujuran. Ia tidak segan-segan memberikan kritik kepada diri dan keluarganya. Dalam buku ini, Syafii Maarif juga mengemukakan pandangan-

37 Ahmad Syafii Maarif, Titik-Titik Kisar dalam Perjalananku: Otobiografi (Yogyakarta: Ombak, 2006). 
pandangannya tentang realitas

pluralisme agama. Di sinilah

persoalan penting yang terkandung dalam buku ini.

5. Tuhan Menyapa Kita. ${ }^{38}$ Karya ini tergolong buku semi utuh. Isinya merupakan kumpulan makalah ilmiah dan beberapa tulisannya di berbagai media massa. Dalam buku ini ia menjelaskan perlunya beragama yang menyapa kemanusiaan. Agama (Islam) menurutnya harus turut serta menyelesaikan nestapa yang diderita umat manusia.

6. Meluruskan Makna Jihad: Cerdas Beragama Ikhlas Beramal. $^{39}$ Karya ini merupakan kumpulan khutbah Jum'at. Dalam buku ini Syafii Maarif menjelaskan makna Jihad yang sesungguhnya, jihad bukan diartikan dengan qitāl (perang) saja, tapi juga membantu orang-orang yang

${ }^{38}$ Ahmad Syafii Maarif, Tuhan Menyapa Kita ( Jakarta: Grafindo, 2006).

39 Ahmad Syafii Maarif, Meluruskan Makna Jihad: Cerdas Beragama Ikhlas Beramal (Jakarta: CMM, 2005). membutuhkan. Jihad yang disalah artikan akan melahirkan stigma bagi Islam, juga nestapa bagi eksistensi manusia itu sendiri.

7. Menerobos Kemelut: Refleksi Cendekiawan Muslim. ${ }^{40}$ Karya ini termasuk buku populer. Dalam buku ini ia memaparkan kondisi bangsa yang kian terpuruk. Syafii Maarif mengajak berbagai lapisan bangsa untuk tetap memelihara optimisme di tengah berbagai persoalan tersebut.

8. Menggugah Nurani Bangsa. ${ }^{41}$ Karya ini termasuk buku semi utuh. Dalam buku ini Syafii Maarif mengajak berbagai elemen bangsa untuk bersamasama memperbaiki kondisi bangsa. Langkah-langkah mendasar untuk memperbaiki kondisi bangsa ini mesti dimulai dari diri sendiri.
40 Ahmad Syafii Maarif, Menerobos Kemelut: Refleksi Cendekiawan Muslim (Jakarta: Grafindo, 2005).

${ }^{41}$ Ahmad Syafii Maarif, Menggugah Nurani Bangsa (Jakarta: MAARIF Institute, 2005). 
9. Mencari Autentisitas di Tengah Kegalauan. ${ }^{42}$ Karya ini termasuk buku semi utuh. Buku ini menunjukkan kegalauan Syafii Maarif menatap kondisi bangsa. Di antara persoalan menarik yang ia angkat adalah jauhnya bangsa Indonesia dari pengamalan falsafah negara yaitu Pancasila.

10. Masa Depan Bangsa dalam Taruhan. ${ }^{43}$ Karya ini termasuk buku populer. Di dalam buku ini Syafii Maarif mendorong setiap anak bangsa untuk berpikir kritis. Ia juga menganjurkan agar kekuasaan yang sedang berlangsung (di bawah Presiden Abdurrahman Wahid (1940-2009), kala itu) harus tetap dikawal. Agar kekuasaan yang dipegang seseorang tetap berpihak pada kepentingan bersama.

\section{Independensi}

\section{Muhammadiyah: Di Tengah}

42 Ahmad Syafii Maarif, Mencari Autentisitas di Tengah Kegalauan (Jakarta: PSAP, 2004).

${ }^{43}$ Ahmad Syafii Maarif, Masa Depan Bangsa dalam Taruhan (Yogyakarta: Pustaka SM, 2000).
Pergumulan Pemikiran Islam dan Politik. ${ }^{44}$ Buku populer. Di dalam buku ini Syafii Maarif menjelaskan bahwa Muhammadiyah selalu berhadapan dengan berbagai kepentingan politik yang terkadang dilematis. Karenanya, Muhammadiyah harus tetap memantapkan dirinya sebagai ormas Islam yang tidak berafiliasi dengan partai politik mana pun.

12. Ibnu Khaldun dalam Pandangan Penulis Barat dan Timur. $^{45}$ Karya ini termasuk buku utuh. Di dalamnya Syafii Maarif menjelaskan bahwa Ibnu Khaldun sesungguhnya salah seorang dari ilmuwan Islam yang besar jasanya dalam pengembangan ilmuilmu sosial. Hal itu dapat dibuktikan dalam "ilm alumrān" yang empiris dan sistematis. Khaldun, menurut

${ }^{44}$ Ahmad Syafii Maarif, Independensi Muhammadiyah: Di Tengah Pergumulan Pemikiran Islam dan Politik (Jakarta: Pustaka Cidesindo, 2000).

${ }_{45}$ Ahmad Syafii Maarif, Ibnu Khaldun dalam Pandangan Penulis Barat (Jakarta: Gema Insani Pers, 1996). 
Syafii Maarif, dapat

disejajarkan dengan Niccollo

Machiavelli (1469-1527) dan

August Comte (1798-1857).

13. Membumikan Islam. ${ }^{46}$ Karya ini termasuk buku populer. Dalam buku ini Syafii Maarif mengulas tentang Tuhan, manusia, alam dan lain-lain, selain cara berdakwah agar materi dakwah diterima secara baik. Ia juga menegaskan bahwa Islam mesti dibawa secara real ke tengah-tengah masyarakat agar menyentuh setiap sisi kehidupan. Dengan demikian Islam akan dirasakan kehadirannya sekaligus manfaatnya oleh semua manusia.

\section{Islam dan Politik di Indonesia}

pada Masa Demokrasi Terpimpin (1950-1965). ${ }^{47}$ Buku ini menguraikan peta politik umat Islam yang

${ }^{46}$ Ahmad Syafii Maarif, Membumikan Islam (Yogyakarta: Pustaka Pelajar, 1995).

47 Ahmad Syafii Maarif, Islam dan Politik di Indonesia pada Masa Demokrasi Terpimpin (1950-1965) (Yogyakarta: UIN Sunan Kalijaga Press, 1988). Buku ini merupakan terjemahan dari tesis Syafii Maarif di Departemen Sejarah Universitas Ohio, Amerika Serikat. sudah memberikan kontribusi terhadap perkembangan Negara Indonesia, terutama di masa demokrasi terpimpin secara komprehensif. Namun karena perbedaan visi yang ada, akhirnya partai-partai Islam menjadi lemah. Partai Islam terpecah ke dalam dua kelompok, yaitu: pertama, kritis dan kedua, pro pemerintah. Buku ini juga memotret sikap pragmatis partai-partai Islam dalam meraih keuntungan.

15. Peta Bumi Intelektualisme Islam di Indonesia. ${ }^{48}$ Karya ini termasuk buku populer. Di dalam buku ini Syafii Maarif menjelaskan bahwa Islam sedang mendapat tantangan dari peradaban Barat sekuler. Karena itu, Islam perlu merumuskan berbagai strategi untuk menghadapinya jika tidak ingin tergerus peradaban itu.

16. Islam dan Masalah Kenegaraan: Studi Tentang

48 Ahmad Syafii Maarif, Peta Bumi Intelektualisme Islam di Indonesia (Bandung: Mizan, 1993). 


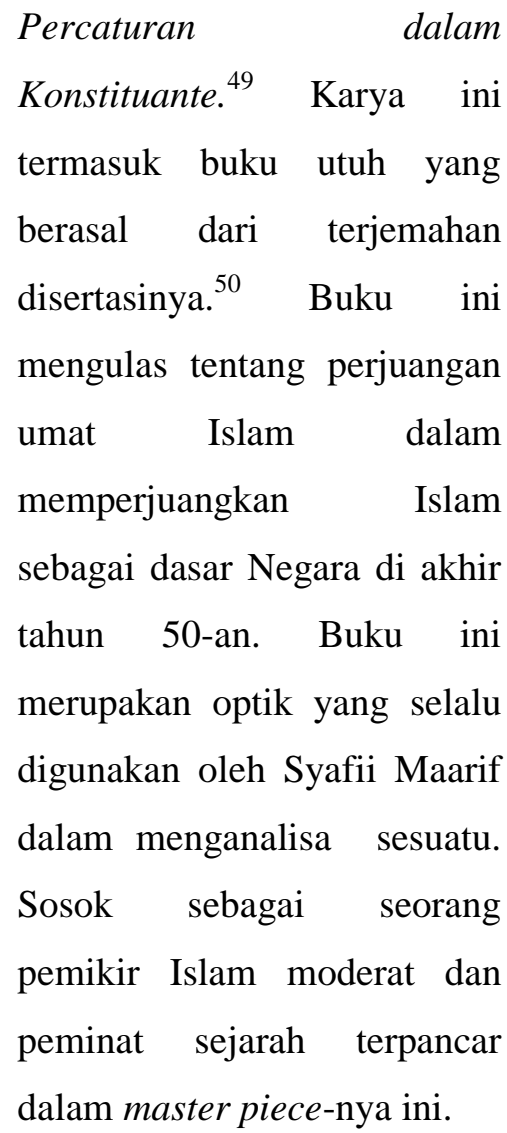

17. Al-Qur'an, Realitas Sosial dan Limbo Sejarah. ${ }^{51}$ Karya ini termasuk buku populer. Di dalamnya Syafii Maarif menjelaskan posisi Alquran sebagai kitab suci yang

49 Ahmad Syafii Maarif, Islam dan Masalah Kenegaraan; Studi Tentang Percaturan dalam Konstituante (Jakarta: LP3ES, 1985).

50 Judul asli disertasi itu adalah: "Islam as the Basis of State: A Study of the Islamic Political Ideas as Reflected in the Constituent Assembly Debates in Indonesia."

51 Ahmad Syafii Maarif, Alquran, Realitas Sosial dan Limbo Sejarah (Bandung: 1985). meliputi berbagai aspek

kehidupan.

Beberapa buku yang ditulis Syafii Maarif tidak dapat dilacak, mengingat karya-karya itu diterbitkan pada awal tahun 70-an dan 80-an. Beberapa buku dimaksud adalah:

1. Mengapa Vietnam Jatuh Seluruhnya ke Tangan Komunis. $^{52}$

2. Dinamika Islam. ${ }^{53}$

3. Islam, Mengapa Tidak $?^{54}$

4. Percik-Percik Pemikiran Iqbal. $^{55}$

5. Aspirasi Umat Islam Indonesia. $^{56}$

6. Duta Islam untuk Dunia Modern. ${ }^{57}$

7. Orientaslime dan Humanisme Sekular. ${ }^{58}$

52 Ahmad Syafii Maarif, Mengapa Vietnam Jatuh Seluruhnya ke Tangan Komunis (Yogyakarta: FKIS-FKIP, 1975).

53 Ahmad Syafii Maarif, Dinamika Islam (Yogyakarta: Shalahuddin Pers, 1984).

54 Ahmad Syafii Maarif, Islam, Mengapa Tidak? (Yogyakarta: Shalahuddin Pers, 1984).

55 Ahmad Syafii Maarif, Percik-Percik Pemikiran Iqbal (Yogyakarta: Shalahuddin Pers, 1984).

56 Ahmad Syafii Maarif, Aspirasi Umat Islam Indonesia. Kota, penerbit dan tahun terbit tidak terlacak.

57 Ahmad Syafii Maarif, Duta Islam untuk Dunia Modern (Yogyakarta: Shalahuddin Press, 1983). 


\section{E. Penutup}

Syafii Maarif merupakan salah satu tokoh pemikiran Islam yang memiliki model gagasan tersendiri. Kehadirannya turut memperkaya perdebatan akademik di Indonesia, bahkan di dunia. Syafii Maarif yang lahir dan dibesarkan dalam kultur Minang, secara sosial dan intelektual, dipengaruhi oleh kultur yang dekat dengan ajaran Islam itu. Keunikan model pemikiran keislamannya terletak pada pendekatan sejarah yang selalu ia gunakan dalam menoropong berbagai persoalan. Namun demikian, Syafii Maarif tetap menempatkan Alquran sebagai alas berpikir dan nilai-nilai utama dalam kerangka berpikir yang dibangunnya.

\section{Daftar Pustaka}

Abdurrahman, Moeslim. Islam sebagai Kritik Sosial. Jakarta: Erlangga, 2003.

Maarif, Ahmad Syafii. Gilad Atzmon: Catatan Kritikal tentang Palestina dan Masa Depan

${ }^{58}$ Ahmad Syafii Maarif, Orientaslime dan Humanisme Sekular (Yogyakarta: Salahuddin Press, 1983).
Zionisme. Bandung: Mizan dan MAARIF Institute, 2012. Al-Qur'an dan Realitas Umat. Jakarta: Republika, 2010. ---------. "Masa Depan Kebebasan dan Kerukunan Beragama di Indonesia." Kata pengantar untuk buku Tore Lindolm, ed. Kebebasan Beragama atau Berkeyakinan: Seberapa Jauh? Yogyakarta: Kanisius, 2010.

----------. Islam dalam Bingkai Keindonesiaan dan Kemanusiaan: Sebuah Refleksi Sejarah. Bandung: Mizan, 2009. ---------. "Manusia Multi Perhatian". Dalam Forum Mangunwijaya IV. Peziarahan Panjang Humanisme Mangunwijaya. Jakarta: Kompas, 2009.

\section{---------. Titik-Titik Kisar dalam Perjalananku: Otobiografi.} Yogyakarta: Ombak, 2006.

--------. Tuhan Menyapa Kita. Jakarta: Grafindo, 2006.

---------. "Keterkaitan antara Sejarah, Filsafat dan Agama". Dalam Pramono Ubaid Tanthowi, ed., Begawan Muhammadiyah: Bunga Rampai Pidato Pengukuhan Guru Besar Tokoh 
Muhammadiyah. Jakarta: PSAP, 2005.

. Meluruskan Makna Jihad:

Cerdas Beragama Ikhlas

Beramal. Jakarta: CMM, 2005.

--------. Menerobos Kemelut:

Refleksi Cendekiawan Muslim.

Jakarta: Grafindo, 2005.

-. Menggugah Nurani Bangsa.

Jakarta: MAARIF Institute,

2005.

Mencari Autentisitas di

Tengah Kegalauan. Jakarta:

PSAP, 2004.

--------. Masa Depan Bangsa dalam

Taruhan. Yogyakarta: Pustaka

SM, 2000.

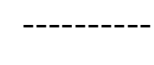

Independensi

Muhammadiyah: Di Tengah

Pergumulan Pemikiran Islam

dan Politik. Jakarta: Pustaka

Cidesindo, 2000.

-------. Ibnu Khaldun dalam

Pandangan Penulis Barat.

Jakarta: Gema Insani Pers,

1996.

---------. Islam dan Politik: Teori

Belah Bambu Masa Demokrasi

Terpimpin (1959-1965). Jakarta:

Gema Insani Pers, 1996.
----------. Peta Bumi Intelektualisme Islam di Indonesia. Bandung: Mizan, 1993.

-------. Islam dan Masalah
Kenegaraan: Studi Tentang Kenegaraan: Studi Tentang Percaturan dalam Konstituante. Jakarta: LP3ES, 1985.

---------. Al-Qur'an, Realitas Sosial dan Limbo Sejarah. Bandung: 1985. ---------. Percik-Percik Pemikiran Iqbal. Yogyakarta: Shalahuddin Pers, 1984.
Dobbin, Christine E. Islamic Revivalism in A Changing Peasant Economy: Central Sumatera 1784-1847. London: Curzon Press, 1983.

Federspiel, Howard M. Sultans, Shammans \& Sains: Islam and Muslim in South East Asia. Hawai: University of Hawai Press, 2007.

Ito, Es. Negara Kelima: Memperingati 100 Tahun Kebangkitan Nasional. Jakarta: Serambi, 2005.

Kahin, Audrey. Dari Pemberontakan ke Integrasi: Sumatera Barat dan Politik Indonesia 1926- 
1998. Jakarta: Yayasan Obor, 2005.

Kato, Tsuyosi. Adat Minangkabau dan Merantau dalam Perspektif Sejarah. Jakarta: Balai Pustaka, 2005.

Kusnadi. Jaminan Sosial Nelayan. Yogyakarta: LKiS, 2007.

Latif, Yudi. Inteligensia Muslim dan Kuasa; Genealogi Inteligensia Muslim Indonesia Abad ke-20. Bandung: Mizan, 2005.

Poesponegoro, Marwati Djoened dan Nugroho Notosusanto. Sejarah Nasional Indonesia VI: Zaman Jepang dan Zaman Republik Indonesia. Jakarta: Balai Pustaka, 1992.

Suaedi, Ahmad dan Raja Juli Antoni, ed. Para Pembaharu Pemikiran dan Gerakan Islam Asia Tenggara. Jakarta: Seamus, 2009.

Tilaar, H.A.R. Kekuasaan dan Pendidikan: Suatu Tinjauan dari Perspektif Studi Kultural. Magelang: Indonesia Kita, 2003. 